\title{
The Southern Appeal: Dutch Translations of French Romances (c. 1484-c. 1540) in a Western European Perspective
}

\begin{abstract}
French literature was by far the most important source of inspiration for the translation, adaptation and creation of medieval romances in other Western European languages. Although this is already well-established for the manuscript period, the importance of French subject matter after the advent of printing merits further research. This article deals with the early printed transmission of Dutch romances translated from the French until c. 1540. It sheds light on some chronological developments in the reception of these romances in the Low Countries by focusing on the publishers' lists of a number of printers as well as on the texts' longevity. Additionally, this article adopts a synchronic view: in order to understand the international appeal of some works, other Western European translations of these titles are also taken into consideration. It turns out that Dutch and English publishers show an interest in similar French subject matter. However, the Dutch editions reveal a higher degree of interference with the text: they tend to make use of multiple sources, remove the names of historical agents involved in the creation of the romances, or include dramatic and lyrical verses, suggesting the influence of rhetoricians and thereby indicating a more urban public.
\end{abstract}

La littérature française était de loin la plus importante source d'inspiration pour la traduction, l'adaptation et la création de romans médiévaux dans les autres langues de l'Europe occidentale. Cette primauté, désormais largement étudiée pour les siècles des traductions manuscrites, se sera prolongée après l'introduction de l'imprimerie. Le present article interroge donc la transmission imprimée, à ce jour toujours bien moins explorée, de romans néerlandais traduits du français avant c. 1540. Nous nous concentrons pour l'essentiel sur une collection de fonds d'imprimeurs ainsi que sur la longévité des textes, qui devraient nous permettre de jeter une nouvelle lumière sur la réception de ces romans dans les anciens Pays-Bas. S’y ajoute une perspective synchronique: afin de mieux comprendre le rayonnement international de certains textes, nous avons également pris en consideration d'autres traductions dans des langues de l'Europe occidentale. Il s'avère notamment que des imprimeurs néerlandais et anglais s'intéressent plus d'une fois à des sources françaises similaires. Néanmoins, les éditions néerlandaises témoignent d'un degré bien plus élevé d'interventions dans le texte: elles ont tendance à faire usage d'une multitude de sources, à éliminer les noms de personnes impliquées dans la création des romans, ou à inclure des passages lyriques ou dramatiques en vers, ce qui suggère l'intervention de rhétoriqueurs et une reception des ces textes dans des milieux citadins.

Note: I am grateful to Bart Besamusca, Jordi Sánchez-Martí and Frank Willaert for their valuable comments and suggestions.

Elisabeth de Bruijn, University of Antwerp

Ә Open Access. (C) 2019 Elisabeth de Bruijn, published by De Gruyter. (cc)BY-NC-ND This work is licensed under a Creative Commons Attribution-NonCommercial-NoDerivatives 4.0 International License.

https://doi.org/10.1515/9783110563016-004 
Throughout the Middle Ages, France profoundly influenced literary life in Western Europe. Most notably, it was the cradle of numerous vernacular (chivalric) romances, many of which inspired translations or adaptions in other European languages. The lion's share of medieval Dutch romances from the manuscript period was translated from or modelled on romances of French origin. ${ }^{1}$ The first Dutch romances that appeared in the age of print, however, were no translations from the French, but works that were already known through Dutch manuscripts or that were translated from Latin sources. ${ }^{2}$ While romances of French origin came into favour after the move of Gheraert Leeu from Gouda to Antwerp in 1484, they did not manage to outnumber the originally Dutch romances and by no means dominated the market. ${ }^{3}$ Moreover, publishers seem to have become more and more aware of narrative literature that was en vogue in other European languages. As compared to other vernaculars, however, France continued to be the number one supplier of romance subject matter in the period from c. 1484 - c. 1540. This leads to the question which French romances were considered marketable enough to compete with the group of originally Dutch romances and the increasing number of translations from other vernaculars. This article focuses on the printed transmission of Dutch romances translated from the French. It discusses their subsequent publishers - most importantly Jacob Bellaert, Gheraert Leeu and Willem Vorsterman -, considering the way they fitted into the respective publishers' list as well as the texts' longevity. The chronological discussion of the romances helps to assess developments in their reception in the Low Countries. Many of these romances also found their way into other (Western European) languages in the first decades after the advent of print. These translations are taken into consideration as well, as they allow for an examination of their contemporary international appeal and offer insight into those features that are characteristic of the Dutch editions.

1 For a recent overview see Johan Oosterman, 'Franse en Nederlandse letterkunde in middeleeuws Vlaanderen'. In: Literaire bruggenbouwers tussen Nederland en Frankrijk. Receptie, vertaling en cultuuroverdracht sinds de Middeleeuwen. Ed. by Maaike Koffeman, Alicia Montoya and Marc Smeets. Amsterdam 2017, p. 29-47.

2 See the contribution by Besamusca and Willaert in the present volume, p. 49-92. See also Luc. Debaene, De Nederlandse volksboeken. Ontstaan en geschiedenis van de Nederlandse prozaromans, gedrukt tussen 1475 en 1540. 2nd ed. Hulst 1977, p. 302-318.

3 Debaene, De Nederlandse volksboeken (note 2), p. 328-329. 


\section{The Beginning: Jacob Bellaert}

The first to have printed narratives translated from the French was Jacob Bellaert. Somewhere between 10 December 1483 and 5 May 1485 he published an edition of the Historie van Jason, ${ }^{4}$ soon followed by the Vergaderinge der historien van Troyen, which is dated 5 May $1485 .{ }^{5}$ The two texts were translated after the French Histoire de Jason (editio princeps Bruges or Ghent?, c. 1476) ${ }^{6}$ and the Recueil des histoires de Troyes (editio princeps Bruges or Ghent?, $c$. 1474-1475) ${ }^{7}$ respectively. Interestingly, Bellaert also published editions of these French texts, Jason probably between 24 December 1485 and 12 August $1486^{8}$ and the Recueil somewhere between 24 December 1485 and 25 July $1486 .{ }^{9}$ Bellaert's publisher's list indicates only three active years of printing, between 10 December 1483 and 20 August 1486, in which he published some 18 editions. Except for the previously mentioned Jason and the Recueil these are all in Dutch, comprising also other translations "of texts which belonged to the courtly literature of the dukes of Burgundy". ${ }^{10}$

Little is known of Bellaert's personal and professional life. There are several indications that he worked for - or perhaps in collaboration with - Gheraert Leeu, who started a printing business in Gouda, in the Northern Low Countries, in $1477 .{ }^{11}$ For reasons that are still subject to speculation Bellaert began his own business in Haarlem, some 50 kilometres north of Gouda. ${ }^{12}$ While Leeu had published a Troy edition already in 1479 (the Historien van Troyen, based on the authoritative version of Guido de Columnis), both Bellaert's Jason and his

\section{ISTC il00111000; GW M17467.}

5 ISTC il00116000; GW M17453.

6 ISTC il00110930. In her contribution to the catalogue of the recent Bruges exhibition 'Haute Lecture by Colard Mansion', Lotte Hellinga gives the dates 1476-1477, see: Lotte Hellinga 'William Caxton and Colard Mansion'. In: Colard Mansion. Incunabula, Prints and Manuscripts in Medieval Bruges. Ed. by Evelien Hauwaerts, Evelien de Wilde and Ludo Vandamme. Gent 2018, p. 63-69 (p. 69).

7 ISTC il00113000. For the possible date and place of printing and for the identity of the printer (possibly David Aubert for William Caxton?), see Lotte Hellinga, 'William Caxton, Colard Mansion, and the Printer in Type 1'. In: Bulletin du Bibliophile 2011, p. 86-114, an article republished in Lotte Hellinga, Incunabula in Transit. People and Trade. Leiden 2018, p. 286-322.

8 ISTC il00110950; GW M17455.

9 ISTC il00113500; GW M17434.

10 Lotte Hellinga, Texts in Transit. Manuscript to Proof and Print in the Fifteenth Century. Leiden 2014, p. 323.

11 See Hellinga, Texts in Transit (note 10), p. 324.

12 Wilma Keesman, 'Jacob Bellaert en Haarlem'. In: Haarlems Helicon. Literatuur en toneel te Haarlem vóór 1800. Ed. by E.K. Grootes. Hilversum 1993, p. 28-30. 
Vergaderinge were translated after the Burgundian versions by Raoul Lefèvre. ${ }^{13}$ Lefèvre's retellings of the mythological stories date back to c. 1460 (Histoire de Jason) and c. 1464 (Recueil des histoires de Troyes) and were dedicated to duke Philip the Good. ${ }^{14}$ In contrast with the extravagantly illuminated manuscripts of the time, the unillustrated editiones principes of the Recueil and Jason make a sober impression. Bellaert's editions of Jason and the Vergaderinge, on the other hand, are described as 'elitist' and 'luxurious'. ${ }^{15}$ With their large folioformat, their two columns and their large woodcuts, they are indeed reminiscent of the lavish Burgundian codices, as well as of the printed editions of his Bruges colleague Colard Mansion. ${ }^{16}$ That Bellaert's editions targeted an aristocratic clientele is demonstrated by the blank coat of arms in his printer's mark, which allowed owners to fill it out with their own coat of arms by means of an ex libris (Fig. 1). ${ }^{17}$ That Bellaert could also rely on aristocratic patronage is demonstrated by the opening woodcut used for both the Vergaderinge and the Jason, which depicts the coat of arms of the prominent Haarlem family Van Ruyven in the background (Fig. 2). ${ }^{18}$

The translator of the Vergaderinge der historien van Troyen made a very close translation of the French Recueil. ${ }^{19}$ Moreover he literally translated the incipit and prologue that present Duke Philip the Good as the instigator of the French work. The reference to "Roelof die Smit" (the Dutch translation of Raoul Lefèvre) in the incipit and Raoul's portrayal in the opening woodcut, presenting his work to Philip the Good, also alludes to the Burgundian origin of the work. Instead of

13 These Burgundian reworkings of Lefèvre also go back to the Historia destructionis Troiae, see Wilma Keesman, De eindeloze stad. Troje en Trojaanse oorsprongsmythen in de (laat)middeleeuwse en vroegmoderne Nederlanden. Hilversum 2017, p. 47-49.

14 Hellinga, Texts in Transit (note 10), p. 305.

15 De vijfhonderdste verjaring van de boekdrukkunst in de Nederlanden. Catalogus. Brussel 1973, p. 286; Wilma Keesman, 'Jacob Bellaert en Haarlem' (note 12), p. 35.

16 Keesman, De eindeloze stad (note 13), p. 54.

17 Keesman, 'Jacob Bellaert en Haarlem' (note 12), p. 35-36.

18 Keesman, 'Jacob Bellaert en Haarlem' (note 12), p. 41-43.

19 According to Willem Kuiper, some words can only be understood if one knows the French source text, as in the case of kinderen ('to child') as a translation of enfanter ('to give birth'). However, contrary to what Kuiper states, the verb does exist in Dutch (there are several attestations in the sixteenth century and the verb kinden also exists in Low German). See the introduction to Willem Kuiper's online edition 'Die vergaderinge der historien van Troyen'. In: Bibliotheek van de Middelnederlandse letterkunde. Nieuwe digitale reeks. Ed. by Willem Kuiper. Amsterdam 2008-2016 (URL: http://cf.hum.uva.nl/dsp/scriptamanent/bml/Vergaderinge_der_historien_van_ Troyen/Vergaderinge_der_historien_van_Troyen.html). The verb kinderen is found on fol. F2v of Bellaert's 1485 edition, see the facsimile of the copy in the Lessing Rosenwald collection in Washington (Incun. 1485. L 43) (URL: http://hdl.loc.gov/loc.rbc/Rosenwald.0487.1). 


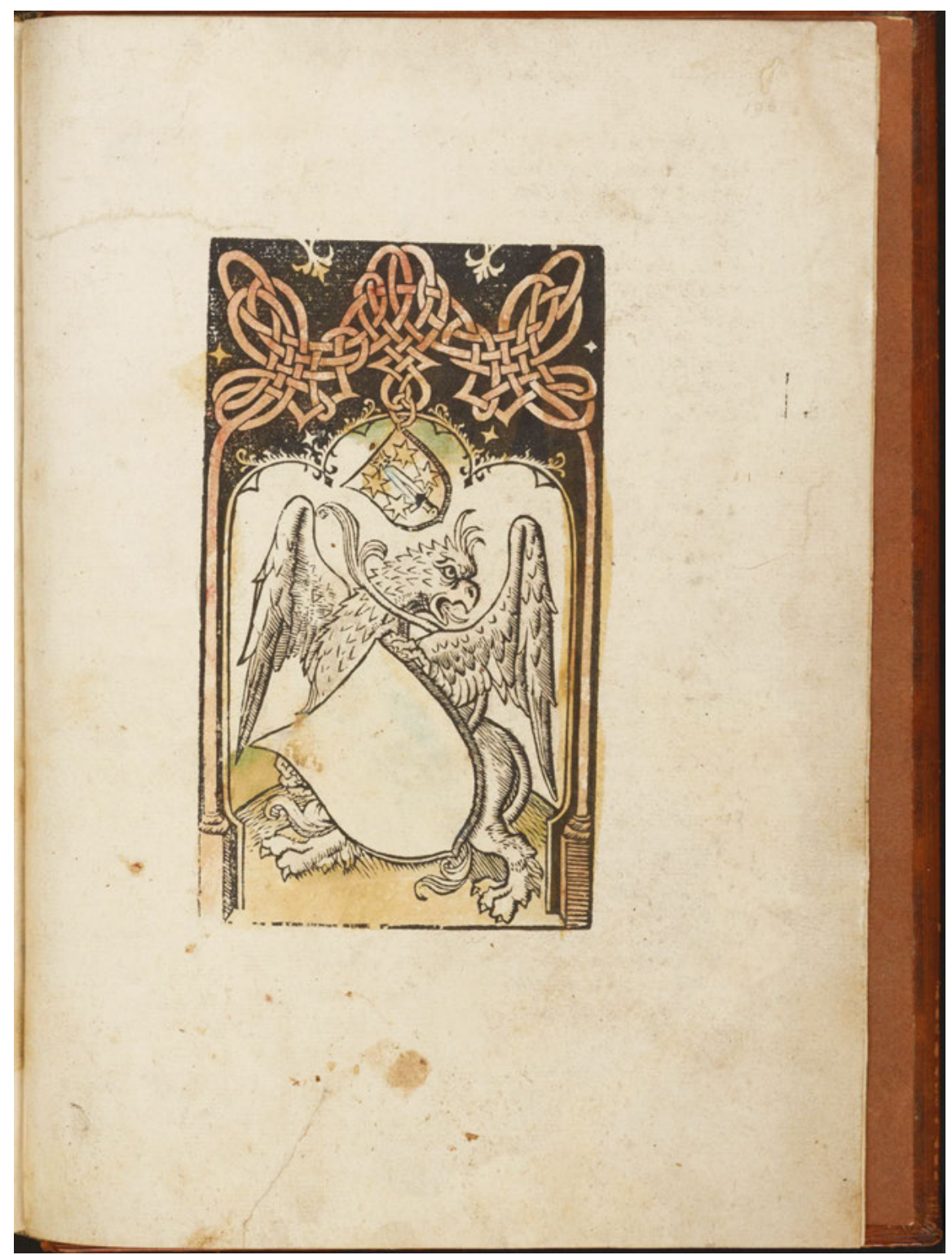

Fig. 1: Printer's mark in the Vergaderinge der historien van Troyen (Haarlem: Bellaert, 1485), fol. z5r. Washington, Library of Congress, Incun. 1485. L 43. 


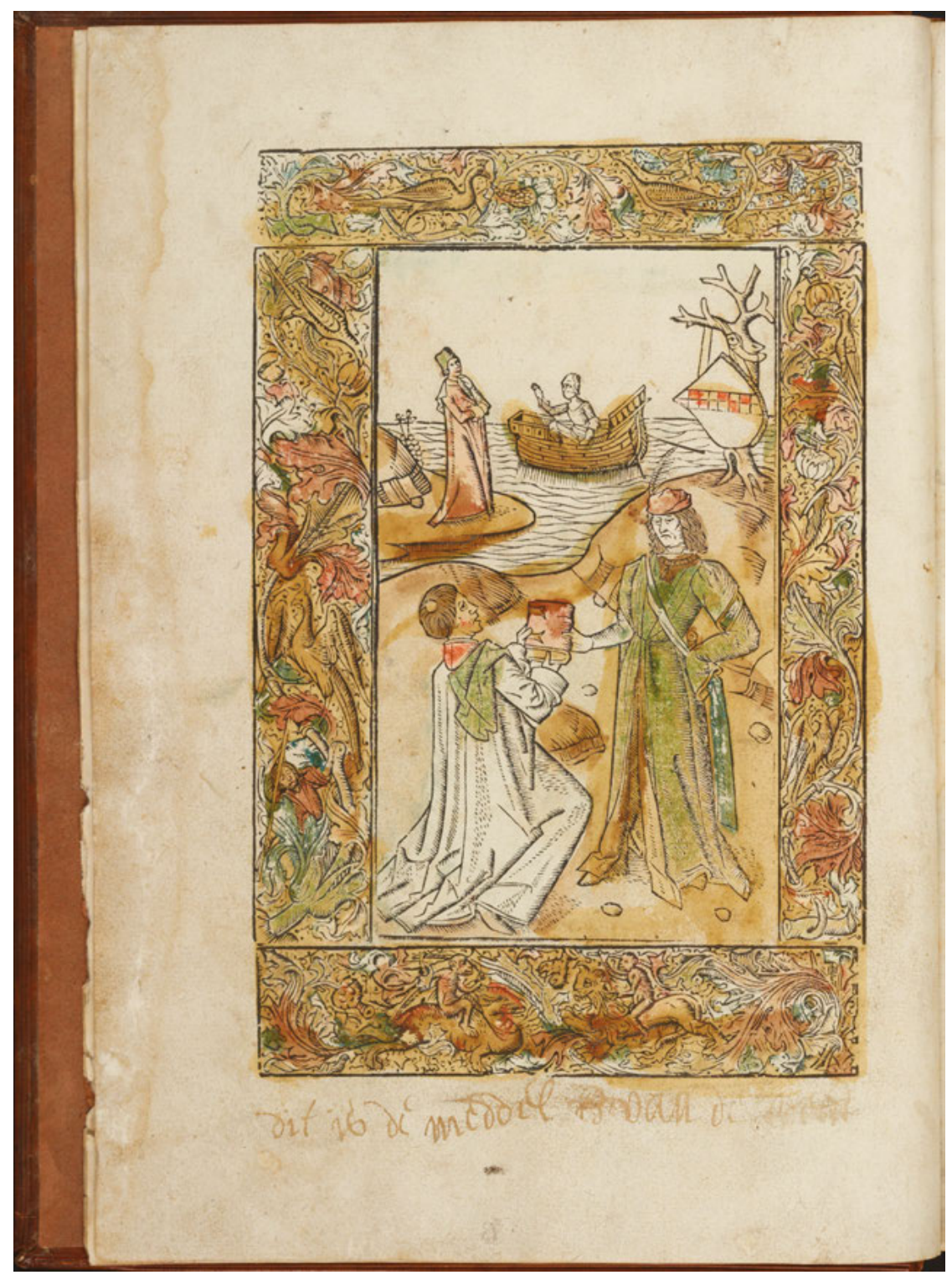

Fig. 2: Opening woodcut of the Vergaderinge der historien van Troyen (Haarlem: Bellaert, 1485), fol. a1v. Washington, Library of Congress, Incun. 1485. L 43. 
looking for new markets, Bellaert seems to have preferred seeking entry into aristocratic circles. The idea that this is what led to his downfall is widely accepted. While it is also possible that Bellaert stopped printing after 1486 because of other reasons (e.g. moving, illness, decease), there are indications that he either overestimated the market for his expensive products or that he underestimated the competition. There are indications that the economic climate in Haarlem was bad at the time and that people were less inclined to spend money on luxurious books. ${ }^{20}$ But it is even more conceivable that the northern elite, probably less affected by the economy, was limited in size and scope and that the market for expensive books was quickly saturated. The fact that the last two books Bellaert printed were French versions of the Jason and the Recueil, can also be taken two ways: either his Dutch versions were relatively successful or he acknowledged his misjudgement and tried to make up for it by starting to print for the French-speaking market. ${ }^{21}$ The lack of an afterlife of the Dutch Vergaderinge, as opposed to its French counterparts, rather points toward the second possibility.

The isolated position of the Dutch Vergaderinge becomes even more telling when compared to the transmission of the French Recueil and the English Recuyell (Table 1). In the Low Countries, Bellaert's Vergaderinge and his Jason only had an afterlife in the shape of Jan van Doesborch's reworkings Van Jason ende Hercules and Die historie vanden stercken Hercules, where the romances were stripped of their Burgundian appearance. ${ }^{22}$ The afterlife of Van Doesborch's editions as well as the rise of other Troy narratives indicates that the Low Countries did not lose their interest in the history of Troy as such but only in Bellaert's version of it. By contrast, Coldiron observes with respect to the French transmission that "[t]he splendidly produced, very finely and heavily illustrated Lyon editions witness that the Burgundian Recueil was, even in France, territory worth seizing and re-seizing". ${ }^{23}$ The English Recuyell - which was probably printed by William Caxton in Flanders and is the first book known to have been printed in the English language - was reprinted several times in the sixteenth and seventeenth

20 Saskia Bogaart, Geleerde kennis in de volkstaal. Van den proprieteyten der dinghen (Haarlem 1485) in perspectief. Hilversum 2004, p. 49-50.

21 Keesman, De eindeloze stad (note 13), p. 57.

22 See below. Besides, the only late-medieval Troy narrative that really seems to have had significant success was the Destructie van Troyen (Antwerp: Van den Dorpe, c. 1496-1500), also discussed below, see Keesman, De eindeloze stad (note 13), p. 61.

23 A.E.B. Coldiron, Printers without Borders. Translation and Textuality in the Renaissance. Cambridge 2015, p. 40. 
Table 1: Printed transmission of the Recueil in French, English and Dutch before 1600.

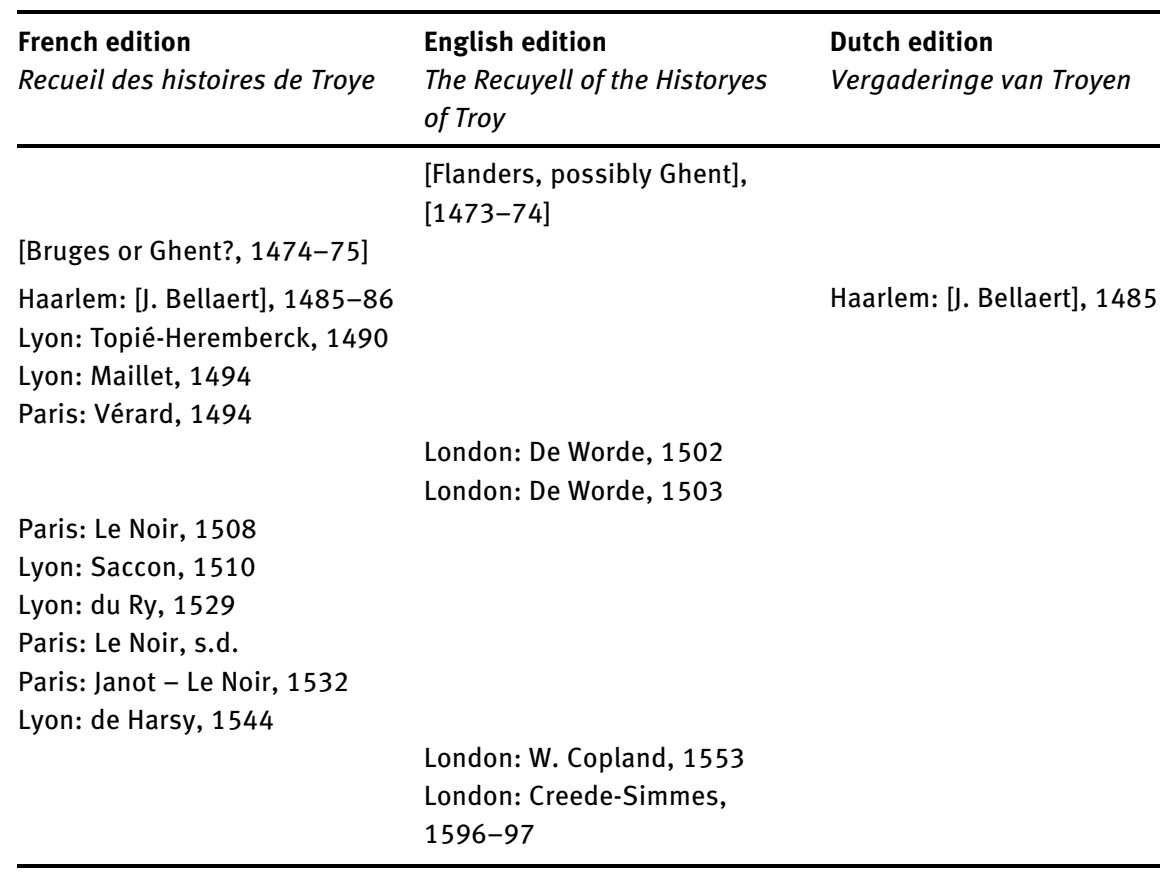

centuries and it coexisted with other Troy stories. ${ }^{24}$ Interestingly, both the quite literally translated content of the French original and the 'Burgundian framing' in the paratext of Caxton's translation persisted in the sixteenth and seventeenth reprints of the English text, indicating not only an interest in the Trojan, but also in the Burgundian past. ${ }^{25}$ While there was an interest in Burgundian manuscripts in the Low Countries, a similar fascination for Burgundian-style printed books has not been attested. This could explain why Bellaert's edition

24 One of these titles was, unsurprisingly, Chaucer's Troilus and Criseyde, printed for the first time by Caxton in 1483 (STC 5094). The English Jason was only reprinted once by Gheraert Leeu in 1492 (STC 15384).

25 In her paragraph 'Troys for England (via Burgundy): reprinting lost empires' Coldiron, Printers without Borders (note 23) states: "Although its own empire fell by 1478, medieval Burgundy remained vibrant in England throughout the sixteenth and seventeenth centuries [...] in art, furniture, tapestries, clothing, and design.” (p. 43-44). She even uses the term 'Troy-gundy' (p. 45) to denote both the ancient-Trojan culture and the frame of the medievalBurgundian culture through which the fall of Troy was mediated: "Troy lost, Burgundy lost: but both are long and carefully preserved, ever in terms of each other, in the printers' blackletter paratexts on generations of readers' shelves" (p. 46). 
failed to gain a foothold. This lack of interest in the Low Countries was apparently found at all social levels, whereas the Burgundian framing in England seems to have appealed to different layers of society, including the higher aristocracy, the gentry, merchants and clerics. ${ }^{26}$ Considering the status of French in Dutch elite circles, it is conceivable that those who were attracted by the Burgundian version of the history of Troy might just as well have read it in French. In fact, the prestige of the French language probably obstructed the blossoming of Burgundian literature in Dutch.

\section{Exploring the Market: Gheraert Leeu}

Unlike Bellaert, Gheraert Leeu must have anticipated the demise of the printing business in the Northern Low Countries in good time. Although Leeu had run a rather successful company in Gouda since 1477, he decided to move his printing house to Antwerp in $1484 .{ }^{27}$ In the following years, this strategical location with its rich hinterland allowed him to print books for the international market. His editions mainly included devotional works and school books, in Dutch and Latin. In 1485 he printed his first Dutch narrative in Antwerp: Esopus. ${ }^{28}$ This version of the text did not just consist of a collection of fables, but it also included the so-called 'vita' of Aesop. ${ }^{29}$ Whereas the few narrative texts which Leeu had published in Gouda had Dutch or Latin sources, his Antwerp Esopus was translated from another vernacular. In the

26 Yu-Chiao Wang, 'Caxton's Romances and Their Early Tudor Readers'. In: Huntington Library Quarterly 67 (2004), p. 173-188. In view of Bellaert's Burgundian orientation it is interesting that "Caxton did not consider the connections to the Burgundian court sufficient for an English market; he did not dedicate The History of Jason to Margaret [Duchess of Burgundy, EdB] but rather to the Prince of Wales” (p. 174).

27 For an introduction to Leeu see Koen Goudriaan, 'Inleiding'. In: Een drukker zoekt publiek. Gheraert Leeu te Gouda 1477-1484. Ed. by Koen Goudriaan et al. Gouda 1993, p. 3-11.

28 ISTC ia00116900; GW 374. For a brief analysis of this publisher's list see Koen Goudriaan, 'Een drukker en zijn markt. Gheraert Leeu (Gouda 1477 - Antwerpen 1492/3)'. In: Madoc 6 (1992), p. 194-205.

29 In contrast to the mere collections of fables, this version of Esopus has a narrative structure and thus meets the criteria of our research corpus (see p. 4 of the Introduction). The different national philologies seem to hold different views on the genre of Esopus. The story does not usually appear in studies on English or French romance. However, in the German tradition, Esopus is sometimes included in collections of prose 'romances'; see, for instance, the contribution by Bertelsmeier-Kierst in the present volume, p. 33 and Christa Bertelsmeier-Kierst, 'Erzählen in Prosa. Zur Entwicklung des deutschen Prosaromans bis 1500'. In: ZfdA 143 (2014), p. 141-165. 
prologue Leeu indicates that he translated the text from Julien Macho's French Esope (Lyon: Huss and Schabeller, 1484). ${ }^{30}$ However, it has been demonstrated that his illustrations as well as some textual details are derived from Steinhöwel's Latin edition of the text (Straßburg: Knoblochtzer, c. 1481), which was taken from his bilingual Latin-German edition (Ulm: Zainer, $c$. $1476 / 77) .^{31}$

Leeu's assessment of the benefit/risk ratio must have taken into account the fact that the French edition had already been printed in Lyon three times in the period 1480-1484, while Steinhöwel's German text was by then printed no less than nine times. ${ }^{32}$ Moreover, in 1484 Caxton had taken his chances by publishing an English translation of Macho's Esope. ${ }^{33}$ The success of Esopus in France and in Germany, as well as the initiative of his English colleague, may have convinced Leeu that he played a safe hand with his Dutch edition of the text. What makes the businessman stand out, however, is that he not merely introduced a successful text into a new market in the shape of a slavish translation from the French (like Caxton), but the fact that his edition was the result of careful compilation. On top of that, Leeu tailored his edition to his Dutch audience by inserting explanations, doublets, (rhymed) proverbs and translations of Latin passages, which are missing in the French editions. ${ }^{34}$ In contrast with Macho and Steinhöwel, Leeu left out some anecdotes on adultery, featuring women who outsmart men. As these passages do appear in Leeu's Latin Esopus edition of 1486, it is believed that they were not deemed appropriate for his vernacular audience. ${ }^{35}$ This example shows that Leeu carefully adjusted his editions in targeting different audiences. The

30 See fol. Aij recto. The editio princeps was published in 1480 by Phillipi and Reinhardi in Lyon. However, Beate Hecker, Julien Macho, Esope. Eingeleitet und herausgegeben nach der Edition von 1486. Hamburg 1982, p. LV, has shown that Leeu used the 1484 edition.

31 Gerd Dicke, Heinrich Steinhöwels 'Esopus' und seine Fortsetzer. Untersuchungen zu einem Bucherfolg der Frühdruckzeit. Tübingen 1994, p. 120 and Paul Wackers, 'Gheraert Leeu as a Printer of Fables and Animal Stories'. In: Reinardus, Yearbook of the International Reynard Society 20 (2007-2008), p. 128-152 (especially p. 146).

32 See for the French editions ISTC ia00118200; ia00118250 and ia00118300. For the German editions see 'Heinrich Steinhöwel, Aesop'. In: MRFH (URL: https://www.mrfh.de/werke.php? werk_id=10\&wahl=textzeugen).

33 ISTC ia00117500; GW 376.

34 Het leven en de fabels van Esopus. Ed. by Hans Rijns and Willem van Bentum. Hilversum 2016, p. 32-33.

35 Het leven en de fabels van Esopus (see note 34), p. 33-34. 
Dutch Esopus was reprinted repeatedly up to the $19^{\text {th }}$ century and as such represents one of the few early printed romances that stood the test of time. ${ }^{36}$

Only two French editions of Paris et Vienne were printed before Leeu himself published another French edition of the text in $1487,{ }^{37}$ possibly following the example of his insular colleague William Caxton, who had published an English edition in $1485 .{ }^{38}$ Unlike Caxton, Leeu included 25 large, unique woodcuts, which he had especially made for this romance. Leeu's French edition was most likely at the basis of the Dutch translation of the text, which he also published in 1487 and which was the first Dutch chivalric romance Leeu printed in Antwerp. ${ }^{39}$ In 1488 Leeu tried his luck with a Low German version of the text, Paris und Vienna. ${ }^{40}$ After the death of William Caxton early in 1492, Leeu did not hesitate to "fill the gap left by Caxton, and in June 1492 he published two books for the English market, significantly two romances, namely Jason and Paris" (Table 2). ${ }^{41}$ Leeu did not have the chance to further develop his market strategies in England, however, due to his sudden death in December of the same year.

For his English edition of Paris and Vienne Leeu reprinted the translation made by Caxton using an English type, but he included the series of woodcuts he used for his Dutch, French and Low German editions and he adjusted the lay-out to make it look like his continental editions. ${ }^{42}$ On the Continent he provided his French-speaking customers with a French version different from the ones provided by Le Roy and Huss, nevertheless using a French type. The Dutch translation is so close to the French that a common French source is assumed: deviations are mainly found at the level of detail and reveal an overall

36 It is one of the 23 titles that are considered the 'canon of volksboeken' on the basis of their transmission up to 1900; see Peter Cuijpers, Van Reynaert de Vos tot Tijl Uilenspiegel. Op zoek naar een canon van volksboeken, 1600-1900. Zutphen 2014, p. 146.

37 ISTC ip00112800; GW 12686.

38 ISTC ip00113500; GW 12691.

39 ISTC ip00113800; GW 12700.

40 ISTC ip00115200; GW 12699.

41 Jordi Sánchez-Martí, 'The Printed Transmission of Medieval Romance from William Caxton to Wynkyn de Worde, 1473-1533'. In: The Transmission of Medieval Romance: Metres, Manuscripts and Early Prints. Ed. by Ad Putter and Judith A. Jefferson. Cambridge 2018, p. 170-190 (quote on p. 180), who also provides additional arguments that Leeu attempted to extend his market into England.

42 Gabriele Diekmann-Dröge, 'Paris und Vienna in Antwerpen. Der mittelniederdeutsche Frühdruck aus der Offizin Gheraert Leeus'. In: Niederdeutsches Wort 26 (1986), p. 55-76 (here p. 57). The inclusion of the woodcuts required seven additional subscriptions, which correspond to the Dutch subscriptions and not to the French or Low German ones, see p. 64. 
Table 2: Printed transmission of Paris et Vienne in French, English, Dutch and Low German before 1600 .

\begin{tabular}{ll}
\hline $\begin{array}{l}\text { French edition } \\
\text { Paris et Vienne }\end{array}$ & $\begin{array}{l}\text { English edition } \\
\text { Paris and Vienne }\end{array}$ \\
\hline [Lyon: Le Roy, 1480] & \\
[Lyon: Huss, 1485] & $\begin{array}{l}\text { Westminster: Caxton, } \\
1485\end{array}$ \\
\end{tabular}

Antwerp: Leeu, 1487

Dutch edition Low German edition

Parijs ende Vienna

Paris unde Vienna

Paris: Meslier, [1491]

Antwerp: Leeu, 1487

Antwerp: Leeu, 1488

Antwerp: Leeu,

[1491-92]

Antwerp: Leeu, 1492

Antwerp: G. Bac,

[1493-95]

Paris: Trepperel,

[1498]

Paris: Trepperel,

[1499]

Paris: Meslier,

[c. 1500]

London: De Worde, 1501-04?

Paris: Le Noir, 1502

London: De Worde, 1501-04?

Antwerp: [Homberch], 1510

Paris: Nourry, 1520

Paris: Trepperel,

[c. 1525]

Paris: Lotrian,

[c. 1530]

Paris: Moderne

[c. 1540]

[Lyon: Chaussard

[Antwerp: ]./Wid. van

Frères 1554]

Paris: Bonfons, [s.d.]

Paris: Calvarin, [s.d.]

Lyon: Rigaud, 1596

Liesveldt, c. 1540]

Troyes: Oudot, [s.d.] 
tendency of the Dutch translator to use more concise phrasings. ${ }^{43}$ Notwithstanding Leeu's efforts to exploit new markets, no reprints are known of the Low German edition of Paris und Vienna. The Dutch edition is known to have been reprinted once by Leeu himself and three times by other publishers, the last time around 1540. Although there are indications that the story of Paris and Vienne was still known in England in the late sixteenth century, no reprints of Caxton's edition were transmitted besides the one by Leeu and the two by De Worde of shortly after $1500 .{ }^{44}$ This contrasts with the extreme popularity of Paris et Vienne in France and Italy. ${ }^{45}$ Despite the story's European outreach, Paris et Vienne did not become the bestseller in the Germanic language areas that Leeu must have hoped for - at least not in terms of reprints. Perhaps its distinct 'medieval' chivalric character prevented the story from becoming a success over time to the same extent that it was across borders.

Around the year 1393 Jean d'Arras wrote his Histoire de Mélusine, a prose text that was to become one of the most popular late medieval romances in French-speaking territories. ${ }^{46}$ The German prose adaptation by Thüring von Ringoltingen, based on the verse reworking by the French author Coudrette

43 Diekmann-Dröge (see note 42), p. 65-66, who also points out one exceptional omission that does affect the content: unlike Leeu's other versions, his French edition has one column of text in which the fate of Paris and Vienna is compared to that of another famous couple: Bueve de Hantone and Jusiana. The editio princeps of the French Bueve de Hantone was only published by Vérard in 1499 and the Dutch translation in 1504; see below. For Leeu's Low German edition a Dutch source similar to - but not identical with - the 1487 edition must have been used (p. 67). Singularities of the Low German edition as compared to the other Leeu editions are of a marginal character too.

44 These indications are a performance by the boys of Westminster School in 1572 and a licence, which was transferred in 1586; see Helen Cooper, 'Going Native: the Caxton and Mainwaring Versions of Paris and Vienne'. In: Travel and Prose Fiction in Early Modern England. Ed. by Nandini Das, special number of The Yearbook of English Studies 41 (2011), p. 21-34 (p. 21). It was only Matthews Mainwaring's entirely rewritten version of 1628 that seems to have sparked a renewed interest in the story in the seventeenth century, see p. 21.

45 See Paris e Vienna, romanzo cavalleresco. Ed. by Anna Maria Babbi. Padova 1991, p. 29-55 for the French transmission and p. 57-121 for the Italian transmission. Printed editions of the prose version are also found in Catalan, Spanish and Latin (p. 129-138), while verse adaptations exist in Yiddish, Swedish, Armenian, Russian and Rumanian (p. 139-153).

46 At least 13 fifteenth-century manuscripts, 6 incunabula and 15 sixteenth-century editions testify to the story's rich afterlife in France; Lydia Zeldenrust, Mutations of an Animal-Human Hybrid Monster: The Western European Mélusine Translations (c. 1400-1600). Doctoral thesis Queen Mary University of London 2015, p. 242-245 provides a list with the French manuscripts and printed editions up to $c .1600$. 
entitled the Roman de Parthenay, has been equally popular. ${ }^{47}$ By the time Leeu published his edition of the Dutch Meluzine, ${ }^{48}$ which is dated 9 February 1491, the story had already been available in 4 French and 10 German editions, not to mention the many manuscripts in both languages. Leeu's translation for the most part goes back to Jean d'Arras' Histoire de Mélusine. ${ }^{49}$ It has been shown recently, however, that the Dutch edition also inserts episodes that are only found in the Roman de Parthenay, thus being the only European translation that is based on both French versions. ${ }^{50}$ Interestingly, the episodes in Leeu's edition are accompanied by three woodcuts that seem to be modelled after those found in German incunabula, indicating that the episodes from the Roman de Parthenay were mediated through a German edition that Leeu used to complement his French example. ${ }^{51}$ This demonstrates that Leeu's edition is not a mere rendition of the French, but, again, the result of careful compilation. Perhaps Leeu aimed at publishing the most complete version possible of the Melusine story, or perhaps his demonstrable close connections with German publishers (as in the case of Esopus) could have simply provided him with materials and woodcuts. ${ }^{52}$ In this respect, Lydia Zeldenrust's suggestion that the episodes from the Roman de Parthenay "were inserted not to tell a more complete story than that of the two French romances, but to complete the story told by the German Melusine images" is worthy of consideration. ${ }^{53}$

However, it would be wrong to assume that Leeu was only driven by the wish to present his audience with an edition that was the result of mere collation. The Dutch translator steers clear of an all too slavish translation and - unlike Bellaert - avoids the use of French idiom. ${ }^{54}$ Moreover, Leeu shows his own signature in the lay-out of his Meluzine by opting for a presentation in two columns instead of one, by inserting several woodcuts different from Steinschaber's

47 The German version was transmitted in 17 manuscripts, 11 incunabula and 20 sixteenthcentury editions; Zeldenrust (see note 46), p. 247-250.

48 ISTC ij00218420; GW 12665.

49 The orthography of names suggests that Leeu's edition has Steinschaber's editio princeps as its source: Bob Duijvestijn, 'Der niederländische Prosaroman von Meluzine; eine Orientierung'. In: Melusine. Actes du Colloque du Centre d'Études Médiévales de l'Université de Picardie Jules Verne, 13 et 14 Janvier 1996. Ed. by Danielle Buschinger and Wolfgang Spiewok. Greifswald 1996, p. 37-50 (p. 42).

50 Zeldenrust (see note 46), p. 141.

51 It is also important to note that the Roman de Parthenay was not printed in French; Zeldenrust (see note 46), p. 157.

52 Zeldenrust (see note 46), p. 157.

53 Zeldenrust (see note 46), p. 157.

54 Duijvestijn (see note 49), p. 44-45. 
edition and by taking over woodcuts from his Paris et Vienne editions. ${ }^{55}$ Another singularity of the Dutch Meluzine is that the text is significantly shorter than its French counterpart due to the avoidance of repetitive elements and descriptive details. Most importantly, however, is the elimination of references to the patron (Duke de Berry), the dedicatee (Marie de Bar) and the supplier of source materials (the count of Salisbury) in the Dutch prologue. ${ }^{56}$ These elements rather seem to have been of importance in the printed tradition of the French and German versions of the text, many of which were owned by members of the nobility. Aristocratic ownership can also be assumed for the independently made English prose and verse translations, which refer to French commissioners as well as the "Erle of Salesbury". ${ }^{7}$ As for the Castilian Melosina, which preserves the dedication to the Duke of Berry, it is known that Margaret of Austria owned a copy of the 1489 edition, while the now-lost Castilian edition of 1512 as well as the 1526 one are dedicated to an unspecified princess. ${ }^{58}$ Although the afterlife of the English Recuyell makes clear that the aristocratic appearance of an edition does not automatically imply an aristocratic readership, it is reasonable to assume that the element of genealogy so characteristic to the Melusine story appealed to members of the nobility. At the risk of taking the reverse argument too far, the lack of attested aristocratic ownership of Middle Dutch romances accords with the tendency to eliminate names of historical agents in Dutch romances (examples of which are given below). ${ }^{59}$ The Dutch Meluzine was reprinted twice in

55 Ina Kok, Woodcuts in Incunabula Printed in the Low Countries. 4 vols. Houten 2013, p. 233 and Zeldenrust (see note 46), p. 146.

56 Although the names of Duke Jean de Berry (patron of Histoire de Mélusine) and the Lord of Parthenay (patron of Roman de Parthenay) are mentioned in the highly abridged epilogue, their appearance there lacks every contextualization and therefore makes a rather alienating impression; Zeldenrust (see note 46), p. 154-155.

57 Zeldenrust (see note 46), p. 175 and 198-199. Both English translations are completely preserved in manuscript (which in itself points to an upper-class audience). Fragments are known of a printed version that is attributed to Wynkyn de Worde; see STC 14648.

58 Zeldenrust (see note 46), p. 115-116 and 121.

59 Rob Resoort, 'De presentatie van drukwerk in de volkstaal in de Nederlanden tot 1501: waar zijn de auteurs, vertalers en opdrachtgevers? Een verkenning'. In: Geschreven en gedrukt. Boekproductie van handschrift naar druk in de overgang van Middeleeuwen naar moderne tijd. Ed. by Herman Pleij, Joris Reynaert et al. Gent 2004, p. 177-206, observes that references to authors and translators are preserved in about $12,5 \%$ of the Dutch incunabula, especially in the domain of 'artes' [non-literary] texts and devotional works. References to the names of French authors/translators are found in some cases (Raoul Lefèvre in the Vergaderinge and Julien Macho in Esopus), while the names of Dutch translators are usually unknown. More research on Dutch authors, translators and commissioners is needed, especially for the post-1500 period. 
Antwerp, by Van Homberch in 1510 and by Verdussen in $1602 .^{60}$ In view of the immense popularity of Melusine in Germany and France, it is remarkable that in English and Dutch territories the romance appears to have been even less popular than Paris et Vienne.

\section{A New Aesthetics: Roland van den Dorpe and Jan van Doesborch}

Not much is known about Roland van den Dorpe, who only published ten mainly devotional and exclusively Dutch - editions between c. 1496 and c. $1500 .{ }^{61}$ Significantly, his only popular romance was a Troy narrative: the Destructie van Troyen, which cannot be dated more accurately. ${ }^{62}$ While the title page suggests that the Trojan war and the love between Troylus and Briseda are equally important, the explicit ("Hier es voleyndt die historie vander amoruesheyt van Troylus ende van Briseda. ende oeck kortelijc ouerlopen die destructie van troyen") emphasizes the love of Troilus and Briseda, while the destruction of Troy is more of a side issue. ${ }^{63}$ In this shift of focus, the edition differs from the 'historiographical' adaptation of Guido de Columnis' Historia destructionis Troiae published by Leeu in 1479 and the 'Burgundian' version published by Bellaert in $1485 .{ }^{64}$ In Van den Dorpe's edition, the parts on the Trojan war are compiled from the texts published by Leeu and Bellaert, but the story of Troylus and Briseda is taken from Boccaccio's Il Filostrato, which was probably known to Van den Dorpe through the French translation by Louis de Beauvau: the Roman de Troyle. ${ }^{65}$ Interestingly, the Roman de Troyle did not make it into print. ${ }^{66}$

60 USTC 436815 (the edition by Verdussen is not catalogued).

61 Anne Rouzet, Dictionnaire des imprimeurs, libraires et éditeurs des $X V^{e}$ et $X V I^{e}$ siècles dans les limites géographiques de la Belgique actuelle. Nieuwkoop 1975, p. 57-58; Vijfhonderdste verjaring (see note 15), p. 506.

62 ISTC ih00281000; GW 12522.

63 "Here ends the history of the love of Troylus and of Briseda and also briefly touched upon the destruction of Troy" (my translation).

64 Note that Leeu again used two sources for his edition, as he completed his translation of Guido de Columnis by parts of Maerlant's adaptation of the Aeneis; see the contribution by Besamusca and Willaert in this volume, p. 70.

65 Keesman, De eindeloze stad (note 13), p. 57.

66 ARLIMA lists 14 manuscripts of Louis de Beauvau's Roman de Troyle: https://www.arlima. net/il/louis_de_beauvau.html. 
While the episodes from the Roman de Troyle were translated into verse, the prose form was used for the parts on the Trojan war. This alternation of prose and verse passages is a technique attested for the first time in the Destructie van Troyen, but which would turn out to become typical for a great number of Dutch romances in the period up to $c .1540 .^{67}$ It differs from the prosimetrum style, also represented in two French editions by Gheraert Leeu, for several reasons. ${ }^{68}$ First, the mix of both forms does not result from the use of both a prose and a verse source text, but the verses appear to have been written especially for the romance. Second, in many romances the verse passages are preceded by speech headings that give them the impression of a dramatic text. Third, in several romances the verses take the shape of refreinen, a form of stanzaic poetry that was cultivated by rederijkers (Rhetoricians), members of the organized Chambers of Rhetoric. Rederijkers dominated literary life in the Southern Low Countries and were also responsible for the production and performance of theatre plays, some titles of which correspond to those of prose romances. It is likely that rederijkers were in some way involved in the composition of the verse passages in Middle Dutch romances.

Verse passages in prose romances did not only enliven the text but also helped to visualize the story in the minds of the reader. ${ }^{69}$ Whether it was for the verse passages or not, Van den Dorpe must have thought that his Destructie van Troyen would appeal to his audience, even though no French printed edition of the Roman de Troyle existed that could provide him with an estimate of his chances. ${ }^{70}$ Indeed, of the three Troy narratives in the Low Countries only the Destructie van Troyen could be considered to have been 'successful' judging by

67 For an overview see Elisabeth de Bruijn, 'Das Spiel der Stimmen. Performative Verspassagen in einigen niederländischen Prosaromanen (ca. 1500-1540)'. In: Stimme und Performanz in der mittelalterlichen Literatur. Ed. by Monica Unzeitig, Nine Miedema and Angela Schrott. Berlin 2017, p. 133-154 (p. 133, note 1) and Luc. Debaene, 'Rederijkers en prozaromans'. In: De gulden passer 27 (1949), p. 1-23.

68 These editions are Van den drie blinden danssen (1482) and Doctrinael des tijts (1486), translations of Pierre Michault's La dance des aveugles and Doctrinal du temps respectively.

69 See Dirk Coigneau, 'Drama in druk, tot circa 1540'. In: Spel en spektakel. Middeleeuws toneel in de Lage Landen. Ed. by Hans van Dijk and Bart Ramakers. Amsterdam 2001 (Nederlandse literatuur en cultuur in de Middeleeuwen 23), p. 201-214 and 352-359. See also De Bruijn, 'Das Spiel der Stimmen' (note 67).

70 According to Willem Kuiper, 'Briseïda. De identiteit van een 'middeleeuws' romanpersonage'. In: Simulacrum, het eigentijdse tijdschrift voor kunst en cultuur, themanummer Identiteit, 12 (2004), p. 17-19, the edition was aimed at an audience of young adults in the vicinity of Antwerp. 
the number of reprints. ${ }^{71}$ While innovations within the text and its presentation could have contributed to its popularity, the historical circumstances might at least have been equally important. It has been demonstrated that the citizens of Antwerp had traditionally shown an interest in its assumed Trojan descent and it is beyond doubt that the city itself offered ideal conditions for commercial success. ${ }^{72}$ Yet the belief in a Trojan descent seems to have been an international phenomenon and the hegemony of Antwerp does not explain the continuing interest in only one of the many available Troy stories. Illustrative in this case is that in France and Germany, the interest in new 'humanist' sources of the Troy legend (e.g. Dares and Dictys or Homeros) coincides with the end of the printed transmission of the stories based on Guido de Columnis around $1540 .{ }^{73}$ In the Low Countries and England, humanist works were published from the second half of the sixteenth century onwards, but they did not shove aside the existing Troy stories. ${ }^{74}$ This reminds us that the life of certain text versions was strongly determined by local interests and traditions.

In the case of Van den Dorpe, the persistent interest in the Destructie van Troyen can also be explained by means of the effective market strategies of his successor, Jan van Doesborch, who took over the printing business from Van den Dorpe's widow around 1501. The first prose romance he published was Buevijn van Austoen in $1504 .^{75}$ It was a highly abbreviated translation from the French Bueve de Hantone (editio princeps Paris: Vérard, 1499), which had by then been put into print three times. ${ }^{76}$ Being reprinted only once by Adriaen van Berghen in $1511,{ }^{77}$ the Dutch translation appears to have been somewhat less successful than the French prose version or the English version in verse, which was transmitted in both manuscript and print. ${ }^{78}$ The fact that not only Van Doesborch's Buevijn

71 The Destructie van Troyen was reprinted in Antwerp by Van Doesborch between 1508-1515 (USTC 436813), by Vorsterman in 1541 (USTC 441931), by Roelants in 1556 (not catalogued) and by Van Ghelen between 1569-1582 (not catalogued); see Keesman, De eindeloze stad (note 13), p. 61, note 109, who also lists the transmission in the seventeenth, eighteenth and nineteenth centuries.

72 Keesman, De eindeloze stad (note 13), p. 64-65 and p. 63 respectively.

73 Keesman, De eindeloze stad (note 13), p. 70.

74 As we have seen, the Burgundian Recuyell continued to be popular in England; see also Keesman, De eindeloze stad (note 13), p. 70.

75 USTC 436691.

76 ISTC ib01275100. See for the sixteenth-century French transmission USTC 26022; 39048; 62906; 55584; 80018 .

77 USTC 436832.

78 See for the sixteenth-century English transmission STC 1987; 1987.5; 1988; 1988.2; 1988.4; 1988.6; 1988.8; 1989; 1990. 
and his reprint of the Destructie van Troyen (c. 1508-1515), but the majority of his romances are characterized by the insertion of verses, indicates that it was Van Doesborch who conventionalized this technique. ${ }^{79}$

Another interesting facet of his publisher's strategy is that Van Doesborch was not so much concerned with what was going on in France. Approximately one third of his editions was published in English, showing a clear orientation towards the English market. ${ }^{80}$ Almost two decades after Leeu's demise, Van Doesborch thus seems to have realized the westward expansion of the printing business that Leeu had in mind. And similar to Leeu, Van Doesborch attempted to immediately cash in by publishing an English and a Dutch edition of the same text. $^{81}$ It is telling that his English edition of, for instance, Frederyke of Jennen (1518) lacks the verse passages with speech headings that we find in Frederick van Jenuen ( ${ }^{\star} c$. 1518). Even the speech headings in the so-called 'reading drama' Mariken van Nieumeghen (probably printed by Van Doesborch before c. 1515) have disappeared in the English reworking Mary of Nemmegen (c. 1515), which is entirely in prose. This underlines the assumption that the interpolation of verses was to a large extent conventional and that Van Doesborch must have been acquainted with literary traditions in England as well as on the Continent. It has been argued that Van Doesborch maintained close connections with Caxton's successor Wynkyn de Worde (active from 1492 until his death in about 1534-1535). ${ }^{82}$ Originating from the Continent, De Worde had grown to be one of the most prolific English printers of that time, his publisher's list comprising about forty romances. ${ }^{83}$ It is likely that Van Doesborch's contacts with De Worde helped him to assess the market oversees.

Van Doesborch's relation with De Worde as well as the evidence suggesting that the technique of compilation was no exception in the creation of early printed romances make it difficult to determine if the source of Van Doesborch's Swan Knight story Helias, ${ }^{84}$ printed in the second decade of the sixteenth century, has been Pierre Desrey's French Genealogie avecques les gestes (editio princeps

79 De Bruijn, 'Das Spiel der Stimmen' (note 67), p. 153. Many of Van Doesborch's prose romances were published by later printers. However, as Van Doesborch had by then already published English translations of these romances, for which a Dutch source can be assumed, the editiones principes of these sources are ascribed to Van Doesborch; see P.J.A. Franssen, 'Jan van Doesborch (?-1536), Printer of English texts'. In: Quaerendo 16 (1986), p. 259-280.

80 Franssen, 'Jan van Doesborch' (note 79).

81 Franssen, 'Jan van Doesborch' (note 79).

82 P.J.A. Franssen, Tussen tekst en publiek. Jan van Doesborch, drukker-uitgever en literator te Antwerpen en Utrecht in de eerste helft van de zestiende eeuw. Amsterdam 1990, p. 47.

83 See the contribution by Jordi Sánchez-Martí in this volume, p. 143-166.

84 USTC 436920. 
Paris: J. Petit, c. 1500) or the English Knight of the Swanne (London: W. de Worde, 1512). ${ }^{85}$ In any case, it is interesting that the English and French editions are very much alike, whereas the Dutch text is again highly abbreviated - except for the inserted verse passages. Only a fragment of Van Doesborch's edition of Helias has survived, but a seventeenth-century edition is considered to be a quite literal rendition. If its prologue already existed in Van Doesborch's edition, it does not refer to any of the historical actors mentioned in the dedication of the French source: King Louis XII and his uncle, Engelbrecht of Cleves, count of Nevers, who are said to be descended from the Swan Knight. ${ }^{86}$ The translator of the English Knight of the Swanne, Robert Copland, remodels the prologue in such a way that now his beneficiary, Duke Edward of Buckingham, becomes a linear descendant of the Swan Knight. In contrast to the French and English versions, the Dutch edition does not contain any reference allowing for a possible situation in an aristocratic environment.

It has recently been shown that Van Doesborch applied a market strategy similar to his Dutch-English parallel productions in the case of Van Jason ende Hercules (8 November 1521) and Die historie vanden stercken Hercules (12 December 1521). ${ }^{87}$ As pointed out above, the sources of Van Doesborch's editions were Bellaert's Jason and the Vergaderinge der historien van Troyen respectively. Both editions were stripped of their 'Burgundian' shell in that they are highly abbreviated, centred on action and sensation and provided with a more extensive illustrative programme. ${ }^{88}$ Although Van Jason ende Hercules and Die historie vanden stercken Hercules were published separately, both the illustrations on the title pages and several (cross)references in the text promote

85 The philological evidence is not conclusive, although arguments in favour of a French source are somewhat stronger. But even in the case of a French source, it is likely that Van Doesborch had at least taken notice of De Worde's English 1512 edition of the Knight of the Swanne, while the latter could also have provided Van Doesborch with a French edition, see Elisabeth de Bruijn, 'Reculer pour mieux sauter: de bronnenproblematiek en de literaire eigenheid van de Middelnederlandse Helias'. In: Verslagen en Mededelingen van de Koninklijke Academie voor Nederlandse Taal- en Letterkunde 126 (2016), p. 227-263.

86 F. Suard, 'Pierre Desrey et La Généalogie de Godefroy de Bouillon'. In: Les épopées de la croisade. Ed. by K.H. Bender and H. Kleber. Special issue of Zeitschrift für französische Sprache und Literatur 11 (1987), p. 151-162 (p. 154).

87 USTC 410164; Bart Besamusca, 'Raoul Lefèvre in Dutch: Two 1521 Editions of the Antwerp Printer Jan van Doesborch'. In: Journal of the Early Book Society 20 (2017), p. 219-232.

88 Bart Besamusca, 'Tekst en beeld in twee drukken van Jan van Doesborch: Van Jason ende Hercules en Die historie van den stercken Hercules'. In: Spiegel der Letteren 59 (2017), p. 1-34. 
the purchase of the editions as a set. ${ }^{89}$ This market strategy was also attested in the case of some editions published by De Worde, from whom Van Doesborch might have learned the approach. ${ }^{90}$ In the Historie van den stercken Hercules Van Doesborch moreover adds a reference to an edition that has the third destruction of Troy and the love of Troylus and Briseda as its theme, thereby including his c. 1508-1515 edition of the Destructie van Troyen in his sales strategy. $^{91}$

\section{Individual Cases: Hendrik Eckert van Homberch and Michiel Hillen van Hoochstraten}

The publisher's list of Hendrik Eckert van Homberch contains devotional works in Latin and Dutch, ancient works, Bibles, scholarly and didactic works and a few chivalric romances. ${ }^{92}$ Nothing in his publisher's list indicates a particular interest in works of French origin. Significantly, Eckert van Homberch reprinted all three of Leeu's Antwerp romances discussed above: Esopus ${ }^{93}$ in 1498 and both Parijs ende Vienna and Meluzine in $1510 .{ }^{94}$ Supposedly in the same year he also published Olyvier van Castillen, ${ }^{95}$ which is the first known Dutch edition of the text and which was reprinted in Antwerp by Jan van Ghelen in $1576 .{ }^{96}$ The Dutch edition of Olyvier thus did not have a spectacular afterlife, nor did the English and German editions of the text. ${ }^{97}$ This sharply contrasts with the popularity of the story in France and - perhaps not surprisingly - in "Olivier's

89 Besamusca, 'Raoul Lefèvre in Dutch' (note 87).

90 Besamusca, 'Raoul Lefèvre in Dutch' (note 87), p. 226-227.

91 Besamusca, 'Raoul Lefèvre in Dutch' (note 87), p. 227.

92 Rouzet (see note 61), p. 60.

93 ISTC ia00117000; GW 00375.

94 USTC 436801 and USTC 436815. Eckert van Homberch also reprinted Seghelijn van Jherusalem twice, see the contribution of Jef Schaeps in this volume, p. 297-324.

95 USTC 436819.

96 USTC 430519.

97 One English edition is known to have been printed by Wynkyn de Worde in 1518. A license to print the story was given to Thomas East on the $12^{\text {th }}$ of March, 1582, but no copy of an edition is known; see The History of Oliver of Castile. Ed. by Robert Edmund Graves. London 1898. The German version goes back to a translation made by Wilhelm Ziely, which was printed by Adam Petri in 1521 (USTC 66894) and 1521/1522 (USTC668941), significantly in Basel, not far from Geneva, where the editio princeps was published. 
fictional fatherland" Spain, where it was repeatedly reprinted in the course of the sixteenth century. ${ }^{98}$

The French Olivier has a prologue in which Philippe Camus is mentioned as the author of the text and count Jean II de Croÿ, count of Chimay, as its beneficiary. References like these encouraged Ana Pairet to assess developments of self-naming and self-representation of historical agents in the editorial tradition of Olivier and Melusine, both texts with a rich transmission. ${ }^{99}$ She observed that the prologue of the Spanish translation reproduces the names of both the beneficiary and the author (even though presented as the 'translator') as found in the French Olivier. It is telling that this historical framing is precisely what is missing in the Dutch edition. Contrary to what we find in research literature, the translator of the Dutch Olyvier did not make use of a Spanish source for his translation, but only used a French example. ${ }^{100}$ He made an even more literal translation of the French prologue than his Castilian colleague, but with one exception: the proper names of the author Philippe Camus (presented as the translator) and instigator Jean II de Croÿ, preserved in the Castilian translation, are replaced by '.N.', the commonly-used abbreviation of 'Nomen'. This is without a doubt the most extreme example of the Dutch disinterest in preserving those names that allude to a story's aristocratic origin.

Ic .N. hopende inder gracien godes hebbe begrepen dese teghenwoerdighe hystorie te translateren ende ouer te setten vanden walsche in duytsche ter begherten ende beuelen van .N.

(I, .N., trusting in the grace of God, have taken it upon me to translate and render the present story from French into Dutch, at the request and order of N.)

98 See for the quote: Ana Pairet, 'Medieval Bestsellers in the Age of Print: Melusine and Olivier de Castille'. In: The Medieval Author in Medieval French Literature. Ed. by Virginie Greene. New York 2006, p. 189-204 (p. 193). For the French incunabula see ISTC ia01178650; ia01178700; ia01178750; ia01178800; ias01178850; ia01178870 and for the sixteenth-century transmission USTC 49881; 64879; 55753; 55944; 49233. See for the Spanish transmission ISTC ia01180000 and USTC 347670; 347671; 347672; 347673; 338115; 344662; 350748; 338116; 350959; 346600; 337881; 351163.

99 Pairet (see note 98).

100 A publication on the French source of the Dutch Olyvier, 'De Nederlandstalige druk van Olyvier van Castillen (circa 1510). Een ongewoon getrouwe vertaling' was recently published in Queeste. Journal of medieval literature in the Low Countries (2018), p. 67-86. It shows that Olyvier was entirely translated from an edition close to the French edition of $c$. 1491-1492 and not - as was believed in the research - after the 1482 edition complemented by a Spanish source. Both the Spanish and the Dutch editions are thus translated following the French edition of $c$. 1491-1492. 
Although Van Homberch's contemporary, Michiel Hillen van Hoochstraten, was the most prolific publisher of the early sixteenth century, the printing of romances does not seem to have been the latter's primary concern. The prose romance Robrecht de Duyvel occupies a rather isolated place in Van Hoochstraten's publisher's list. His edition, dated 1516, was only discovered shortly before 1980, but its existence had been deduced from several sixteenth- and seventeenthcentury indices, one of them mentioning a 1543 edition by Jacob van Liesvelt. ${ }^{101}$ The Dutch translation closely corresponds with the French prose edition of the text, but it also has variants that are found in the English prose edition only (as was the case with Helias), making it difficult to assess the genesis of the text. ${ }^{102}$ It is noteworthy that Olivier de Castille and Robert le Diable, both published in Dutch around or shortly after 1510, met with great popularity in Spain, where translations from the French had difficulties to compete with originally Castilian romances. ${ }^{103}$ There does not seem to be any reason for the fact that the Dutch translations of Olivier de Castille and Robert le Diable were printed shortly after the Spanish editions other than that both romances were highly popular in France, that they contain 'new' - that is to say fifteenth-century prosifications of - romances and that early sixteenth-century editions also existed in English, indicating a European appeal. Both in the Low Countries and in England, however, their popularity did not last.

\section{The Later Years: Willem Vorsterman and Two Decades of Decline}

The four publications of Willem Vorsterman that go back to a French source pale into insignificance with respect to the scope of his publisher's list, which

101 Robrecht de Duyvel. Ed. by Rob Resoort. Muiderberg 1980, p. 24.

102 More research into the source of the Dutch edition is needed, see Franssen, Tussen tekst en publiek (note 82), p. 44. See for the French incunabula transmission ISTC ir00202900; ir00202920; ir00202925; ir00202930; ir00202940; and for the transmission in the sixteenth century (10 editions) Mariagrazia Ricci, 'Robert le Diable'. In: Nouveau Répertoire de mises en prose (XIV $-X V I^{e}$ siècle). Ed. by Maria Colombo Timelli et al. Paris 2014, p. 753-760. For the transmission in England, see STC 21070; 21071; 21071.5, all printed between c. 1500-1517.

103 Daniel Eisenberg, Romances of Chivalry in the Spanish Golden Age. Newark, Delaware 1982, indicates "that the foreign romances of chivalry available in translation were tangential works, having lost whatever influence they may have had in Castile in the fifteenth or earlier centuries" (URL: http://www.cervantesvirtual.com/obra-visor/romances-of-chivalry-in-thespanish-golden-age-0/html/ffcd58ce-82b1-11df-acc7-002185ce6064_37.html). For the transmission in Spain, see USTC 347782; 343558; 351106; 351144; 343234; 348851. 
comprises over 400 titles. Among his romances we find adaptations based on Dutch manuscript texts, namely Margariete van Limborch (1516), Strijt van Roncevale (c. 1520) and Hughe van Bordeus (c. 1540), but also translations from the Low German Frederick van Jenuen (1531, probably first printed by Van Doesborch before 1518) and from the originally Spanish romance Sibilla (c. 1538). Vorsterman is often said to have had a clear business sense. ${ }^{104}$ It may not surprise that he printed mainly those narratives that had demonstrable success. The first translation from an originally French romance he published was his c. 1505 edition of the Destructie van Jherusalem, ${ }^{105}$ reprinted by himself around $1525^{106}$ and by Jacob or Widow Van Liesveldt around $1540 .^{107}$ It is noteworthy that Gheraert Leeu had already published another version of the Destructie van Jherusalem in 1482, using Jacob van Maerlant's rhymed Wrake van Jherusalem, which in turn goes back to Flavius Josephus' De bello judaico. ${ }^{108}$ Interestingly, Vorsterman did not use this 'historiographical' version of the text but chose the originally French 'romantic, naïve, popular history', La Vengeance de nostre seigneur, instead. ${ }^{109}$ His publisher's decision parallels that of Van den Dorpe, who also left Leeu's historiographical edition of the Destructie van Troyen aside and published a 'modernized' edition of the story that enjoyed continued popularity.

Vorsterman's c. 1517 edition of Peeter van Provencen ${ }^{110}$ (translated after the French Pierre de Provence) was published around the same time as Olivier de

104 Yves Vermeulen, Tot profijt en genoegen. Motiveringen voor de produktie van Nederlandstalige gedrukte teksten 1477-1540. Groningen 1986, p. 129.

105 USTC 441789.

106 USTC 410390.

107 USTC 410390.

108 Willem Kuiper, 'Die Destructie van Jherusalem in handschrift en druk'. In: Voortgang, jaarboek voor de neerlandistiek 25 (2007), p. 67-88 (p. 84). This was also observed by Willy Braekman, Die destructie vander stat van Jherusalem. Een Vlaams Volksboek, naar het uniek exemplaar van de Antwerpse druk van Willem Vorsterman (c. 1525). Brugge 1984, p. 6-7.

109 See for the quotation Die destructie vander stat van Jherusalem. Een Vlaams Volksboek, naar het uniek exemplaar van de Antwerpse druk van Willem Vorsterman (ca. 1525). Ed. by Willy Braekman. Brugge 1984, p. 6 (my translation). Future research should reveal if the edition published by Vorsterman goes back to a handwritten version of the Vengeance de nostre seigneur, as suggested by Willem Kuiper's introduction, 'Die Destructie van Jherusalem'. In: Bibliotheek van Middelnederlandse Letterkunde, nieuwe digitale reeks. Ed. by Willem Kuiper 2008-2016 (URL: http://cf.hum.uva.nl/dsp/scriptamanent/bml/Destructie_van_Jherusalem/Destructie van_Jherusalem.html), or an early printed edition, as accepted by Braekman (p. 8). More research into the transmission of the Vengeance is necessary but complex, not least because the lack of uniform titles of the printed Vengeance.

110 USTC 436967. 
Castille and Robert le Diable. There is no evidence that the story ever made it into print in England. The sixteenth-century Spanish translation enjoyed considerable popularity, but it was in Germany that the text was most enthusiastically welcomed, as is shown by the number of reprints of Veit Warbeck's German translation in the course of the sixteenth century and after. ${ }^{111}$ It was not, however, until 1535 that the editio princeps of this German edition was printed, indicating that Vorsterman only relied on the success of the French edition when he printed the first European translation of the story. His Peeter van Provencen edition is a literal translation from the French, with the exception of 28 inserted refreinen, which is the highest number found in a sixteenthcentury prose romance. ${ }^{112}$ These refreinen reappear in the edition's 1565 Antwerp reprint by Claes vanden Wouwere, but they are missing in three other late sixteenth-century editions, in which the French and Dutch versions of the story are printed side by side. ${ }^{113}$ It is likely that these bilingual editions of Peeter van Provencen served as school books, arguably because their "wellknown and highly appreciated subject matter" was found suitable for children in the Low Countries so as to learn French. ${ }^{114}$ Despite its quite innocent content, the Spanish intellectual Juan Luis Vives, who lived in the Southern Low Countries, mentions Peeter van Provencen in his De institutione foeminae christianae (1524) as one of the books that could harm the education of young girls, thereby confirming that the work was at least partially aimed at a youthful readership. ${ }^{115}$

After the publication of Peeter of Provencen in c. 1517, no new Dutch romances of French origin seem to have been published up to around 1540, neither by Vorsterman nor by other publishers. Also in general, the number of 'volksboeken' published in the 20s and 30s of the sixteenth century is significantly

111 The appendix to Pierre de Provence et la Belle Maguelonne. Ed. by Anna Maria Babbi. Soveria Mannelli 2003, p. 276-278 lists seven Castilian editions and no fewer than 31 German editions for the sixteenth century.

112 Pierre Vinck, 'Het volksboek Die Historie van Peeter van Provencen ende die schoone Maghelone van Napels'. In: Jaarboek De Fonteine 27 (1976-1977), p. 3-45. The source of the edition has been a corrupt version of the so-called French ' $\mathrm{C}$ ' version, printed for the first time around 1485 in Lyon (p. 26).

113 The 1565 edition is not catalogued in the USTC. The bilingual editions were printed by Jan van Waesberghe in 1560 (USTC 59081 and 63951) and 1587 (USTC 79810).

114 Rob Resoort, 'Een proper profitelijc boec. Eind vijftiende en zestiende eeuw'. In: De hele Bibelebontse berg. De geschiedenis van het kinderboek in Nederland en Vlaanderen van de middeleeuwen tot heden. Ed. by Nettie Heimeriks and Willem van Toorn. Amsterdam 1989, p. 41-103 (p. 71).

115 Resoort, 'Een proper profitelijc boec' (note 114), p. 59. 
lower than in the previous two decades. Works that do appear in this period include reprints of earlier romances as well as romances translated from other languages, such as English (Jacke, Antwerp: Hillen van Hoochstraten, 1528), Low German (Frederick van Jenuen, Antwerp: Vorsterman, 1531, but probably first printed by Van Doesborch before 1518) and, for the first time, Spanish (Turias ende Floreta, Brussels: Van der Noot, 1523; Sibilla, Antwerp: Vorsterman, c. 1538). The wider international orientation is one possible explanation for the decline of translations from originally French romances. More 'literary' explanations can be sought in the changes of literary taste or the appeal of other genres than romances. Economically speaking, it could also have been possible that the market was saturated in some way. Previous research has shown that the number of copies increased in the period up to 1540 but this does not mean that the demand grew accordingly. ${ }^{116}$ Furthermore, the early sixteenth century witnessed the first waves of censorship and the humanist offensive against fictional stories - notably the Spanish humanist Vives who explicitly mentions some Dutch romances as poisonous reading. On a much more practical level, one should be aware of the fact that the printing of romances was strongly connected to certain individuals, such as Leeu and Van Doesborch and as such dependent on the initiative of those who applied themselves to romances - and those who could afford them. This trend is also visible in Germany, France and perhaps most noticeably, England, where the supply of romances decreases after De Worde's passing until William Copland renewed production in the mid-1550s. ${ }^{117}$

Somewhere around 1540, Vorsterman published his edition of de Verloren sone, a translation from the French L'Enfant Prodigue par personnaiges, which resembles contemporary romances in its formal presentation. ${ }^{118}$ The content of the story is abbreviated to such an extent that it only makes up half of the French verse text. A remarkable feature is that the Dutch translation does adopt the verse form of its example but inserts prose sections at the beginning of each

116 According to Peter Cuijpers, Teksten als koopwaar. Vroege drukkers verkennen de markt: een kwantitatieve analyse van de productie van Nederlandstalige boeken (tot circa 1550) en de 'lezershulp' in de seculiere prozateksten. Nieuwkoop 1998, p. 53, the average print run of 300 copies in 1480 gradually increased to an average of 500 in 1540. Little is known, however, about the demand.

117 See the contribution of Sánchez-Martí in the present volume, p. 143-166.

118 USTC 410388. It is still under debate if the French text was printed by Alain Lotrian around 1529 or by Jean Janot and the widow of Jean Trepperel between 1510 and 1517, see An Faems, 'De verloren sone: een parabel int langhe'. In: Vechten met de engel. Herschrijven in de Nederlandstalige literatuur. Ed. by Ben van Humbeeck, Valerie Rousseau and Cin Windey. Antwerp 2009, p. 185-206 (p. 191). 
chapter to smooth the transition between the chapters. ${ }^{119}$ The result of this procedure is a romance that is characterized by the mix of prose and verse that audiences in the Low Countries were accustomed to. ${ }^{120}$

The last known translation from the French published by Vorsterman is Galien Rethore, which was only brought to academic notice in the spring of 2016, when it was sold at auction. Though the date of the edition is described in the auction catalogue as "before 1540?", it cannot be determined any further than the active years of Vorsterman between $c .1504$ and $c .1543 .{ }^{121}$ A transcription of the Dutch edition, published synoptically along with Antoine Vérard's editio princeps from around 1500, has been published online by Willem Kuiper. ${ }^{122}$ His initial findings about the translation indicate that the text is highly abbreviated, leaving out everything that does not directly relate to the adventures of the protagonist. ${ }^{123}$ It shows signs of expurgation as well, arguably because the translation was aimed at an audience of young adults (something Kuiper also assumes for many other Dutch romances). ${ }^{124}$ In contrast with his French source, Vorsterman's edition is illustrated with many woodcuts, covering both columns of the folio edition. This presentation calls for further study, especially in the light of Vorsterman's other romance editions, the majority of which are in quarto. Notwithstanding the general decrease of folio editions in the course of the sixteenth century, the format was used in Claes van den Wouwere's 1564 edition of Ponthus en Sydonie as well as in Jan van Ghelen's 1576 reprint of Olyvier van Castillen. Both publishers preferred smaller formats for other works in this period. Apparently, in their editions of medieval romance material they applied conventional schemes - and even used the by then outdated folio format which may have provided the audience with a sense of identifiability and familiarity.

119 Faems (see note 118), p. 193.

120 De Bruijn, 'Das Spiel der Stimmen' (note 67), p. 151.

121 Elisabeth de Bruijn, 'Galien Rethore herontdekt'. In: Madoc 31 (2017), p. 75-82. In handwritten notes by the edition's former owner, Willy Braekman, the edition is dated c. 1520-1525, but no motivation for this dating is given. Both the edition and the notes are preserved in the Hendrik Conscience Heritage Library in Antwerp.

122 Willem Kuiper, 'Galien Rethore: de editie'. In: Neerlandistiek. Online tijdschrift voor taalen letterkundig onderzoek (March 23, 2018) (URL: http://www.neerlandistiek.nl/2017/02/ga lien-rethore-de-editie/).

123 Willem Kuiper, 'Galien Rethore online'. In: Neerlandistiek. Online tijdschrift voor taal- en letterkundig onderzoek (March 23, 2018) (URL: http://www.neerlandistiek.nl/2016/12/galienrethore-on-line/).

124 Kuiper, 'Galien Rethore: de editie' (note 122). 


\section{Conclusion}

In the era of print, some translations were initially made from French romances. However, the orientation of Dutch publishers gradually became wider and they also used source texts from other centres of European literature. The editions by Gheraert Leeu indicate that his printing business had been international rather than Francophone already at an early stage, both in its input (e.g. the use of a Latin Knoblochtzer edition for his Esopus) and in its output (shown by his Paris et Vienne editions in Low German and - after Caxton's demise - in English). Jan van Doesborch's romance production had been predominantly oriented towards the English market, whereas Willem Vorsterman published romances of various European origins. The Low Countries seem to have discovered their new South in the late 20s of the sixteenth century, when the first works of Spanish origin were translated. Notably, almost all romances of French origin that did appear in the Low Countries were texts with international appeal, meaning that if a translation was published in Dutch, it had most likely also been published in English, Spanish or, to a lesser extent, German. Only Roland van den Dorpe seems to have deviated from this rule by using a manuscript of the Roman de Troyle to complement his edition of the Destructie van Troyen. In their choice of French materials, the Low Countries often sided with England, in that printers on both sides of the Channel showed an interest in the French Recueil, Jason, Esopus, Paris et Vienne, Melusine, Bueve de Hantone, the Swan Knight, Olivier de Castille and Robert le Diable. Many of these originally French stories were either not printed in Germany, or they drew on different versions of the text (as in the case of Esopus, Meluzine and Pierre de Provence).

Despite the fact that the Dutch adaptations often go back to the same French sources as the Spanish or English translations, they show their own signature in the way they appropriate the material. As a rule, Dutch translations of French romances are shorter than their French examples because they are abbreviated, whether a little or very much so. Many of these abbreviations result in a plain, understandable translation that would appeal to a youthful audience, as was suggested for many of the discussed romances. ${ }^{125}$ The fact that all discussed romances (with the exception of the Verloren sone) appear on early seventeenth-century lists of censored school books indicates that a century later, young adults constituted an important share of these romances' readership. Another characteristic of the Dutch translations is the tendency to interfere with the text. In the incunabula period, Leeu's Esopus, Melusine and Paris

125 Resoort, 'Een proper profitelijc boec' (note 114), p. 43-72. 
et Vienne editions as well as Van den Dorpe's Destructie van Troyen testify to the trend to combine texts from multiple sources, while many romances published between $c$. 1500-1540 insert verse passages, which come in the shape of refreinen or dramatic dialogues. This contrasts with English translations of French sources, which "tended to be strictly faithful to their originals". ${ }^{126}$ The verse passages, which are most likely composed by rederijkers, offer the most concrete clue for situating many Dutch prose romances in an urban middle class environment. It is tempting to connect this to the highly puzzling Dutch tendency to remove the names of the historical actors involved in the French originals. In the surrounding territories, printed romances were still suffused with the spirit of the stories' aristocratic origin and many chivalric narratives enjoyed a continued interest in the late sixteenth century. The lack of reprints of stories like Parijs ende Vienna, Olyvier van Castillen, Peeter van Provencen and Galien Rhetore in the Low Countries, on the other hand, suggests that medieval chivalric romances fell out of favour when a new era was born.

\section{Bibliography}

Bertelsmeier-Kierst, Christa, 'Erzählen in Prosa. Zur Entwicklung des deutschen Prosaromans bis 1500'. In: ZfdA 143 (2014), p. 141-165.

Besamusca, Bart, 'Raoul Lefèvre in Dutch: Two 1521 Editions of the Antwerp Printer Jan van Doesborch'. In: Journal of the Early Book Society 20 (2017), p. 219-232.

Besamusca, Bart, 'Tekst en beeld in twee drukken van Jan van Doesborch: Van Jason ende Hercules en Die historie van den stercken Hercules'. In: Spiegel der Letteren 59 (2017), p. 1-34.

Bogaart, Saskia, Geleerde kennis in de volkstaal. Van den proprieteyten der dinghen (Haarlem 1485) in perspectief. Hilversum 2004.

Braekman, Willy, Die destructie vander stat van Jherusalem. Een Vlaams Volksboek, naar het uniek exemplaar van de Antwerpse druk van Willem Vorsterman (c. 1525). Brugge 1984.

Bruijn, Elisabeth de, 'Reculer pour mieux sauter: de bronnenproblematiek en de literaire eigenheid van de Middelnederlandse Helias'. In: Verslagen en Mededelingen van de Koninklijke Academie voor Nederlandse Taal- en Letterkunde 126 (2016), p. 227-263.

Bruijn, Elisabeth de, 'Das Spiel der Stimmen. Performative Verspassagen in einigen niederländischen Prosaromanen (ca. 1500-1540)'. In: Stimme und Performanz in der mittelalterlichen Literatur. Ed. by Monica Unzeitig, Nine Miedema and Angela Schrott. Berlin 2017.

Bruijn, Elisabeth de, ‘Galien Rethore herontdekt’. In: Madoc 31 (2017), p. 75-82.

126 Helen Cooper, 'Prose Romances'. In: A Companion to Middle English Prose. Ed. by A.S.G. Edwards. Cambridge 2014, p. 215-229 (p. 221-222). 
Bruijn, Elisabeth de, 'De Nederlandstalige druk van Olyvier van Castillen (circa 1510). Een ongewoon getrouwe vertaling'. In: Queeste. Journal of medieval literature in the Low Countries 25 (2018), p. 67-86.

Coigneau, Dirk, 'Drama in druk, tot circa 1540'. In: Spel en spektakel. Middeleeuws toneel in de Lage Landen. Ed. by Hans van Dijk and Bart Ramakers. Amsterdam 2001 (Nederlandse literatuur en cultuur in de Middeleeuwen 23), p. 201-214 and 352-359.

Coldiron, A.E.B., Printers without Borders. Translation and Textuality in the Renaissance. Cambridge 2015.

Cooper, Helen, 'Going Native: the Caxton and Mainwaring Versions of Paris and Vienne'. In: Travel and Prose Fiction in Early Modern England. Ed. by Nandini Das, special number of The Yearbook of English Studies 41 (2011), p. 21-34.

Cooper, Helen, 'Prose Romances'. In: A Companion to Middle English Prose. Ed. by A.S.G. Edwards. Cambridge 2014, p. 215-229.

Cuijpers, Peter, Teksten als koopwaar. Vroege drukkers verkennen de markt: een kwantitatieve analyse van de productie van Nederlandstalige boeken (tot circa 1550) en de 'lezershulp' in de seculiere prozateksten. Nieuwkoop 1998.

Cuijpers, Peter, Van Reynaert de Vos tot Tijl Uilenspiegel. Op zoek naar een canon van volksboeken, 1600-1900. Zutphen 2014.

Debaene, Luc., 'Rederijkers en prozaromans'. In: De gulden passer 27 (1949), p. 1-23.

Debaene, Luc., De Nederlandse volksboeken. Ontstaan en geschiedenis van de Nederlandse prozaromans, gedrukt tussen 1475 en 1540. 2nd ed. Hulst 1977.

Dicke, Gerd, Heinrich Steinhöwels 'Esopus' und seine Fortsetzer. Untersuchungen zu einem Bucherfolg der Frühdruckzeit. Tübingen 1994.

Diekmann-Dröge, Gabriele, 'Paris und Vienna in Antwerpen. Der mittelniederdeutsche Frühdruck aus der Offizin Gheraert Leeus'. In: Niederdeutsches Wort 26 (1986), p. 55-76.

Duijvestijn, Bob, 'Der niederländische Prosaroman von Meluzine; eine Orientierung'. In: Melusine. Actes du Colloque du Centre d'Études Médiévales de l'Université de Picardie Jules Verne, 13 et 14 Janvier 1996. Ed. by Danielle Buschinger and Wolfgang Spiewok. Greifswald 1996.

Eisenberg, Daniel, Romances of Chivalry in the Spanish Golden Age. Newark, Delaware 1982.

Faems, An, 'De verloren sone: een parabel int langhe'. In: Vechten met de engel. Herschrijven in de Nederlandstalige literatuur. Ed. by Ben van Humbeeck, Valerie Rousseau and Cin Windey. Antwerp 2009, p. 185-206.

Franssen, P.J.A., 'Jan van Doesborch (?-1536), Printer of English texts'. In: Quaerendo 16 (1986), p. 259-280.

Franssen, P.J.A., Tussen tekst en publiek. Jan van Doesborch, drukker-uitgever en literator te Antwerpen en Utrecht in de eerste helft van de zestiende eeuw. Amsterdam 1990.

Goudriaan, Koen, 'Een drukker en zijn markt. Gheraert Leeu (Gouda 1477 - Antwerpen 1492/ 3)'. In: Madoc 6 (1992), p. 194-205.

Goudriaan, Koen, 'Inleiding'. In: Een drukker zoekt publiek. Gheraert Leeu te Gouda 1477-1484. Ed. by Koen Goudriaan et al. Gouda 1993, p. 3-11.

Hecker, Beate, Julien Macho, Esope. Eingeleitet und herausgegeben nach der Edition von 1486. Hamburg 1982.

Hellinga, Lotte, Texts in Transit. Manuscript to Proof and Print in the Fifteenth Century. Leiden 2014. 
Hellinga, Lotte, 'William Caxton and Colard Mansion'. In: Colard Mansion. Incunabula, Prints and Manuscripts in Medieval Bruges. Ed. by Evelien Hauwaerts, Evelien de Wilde and Ludo Vandamme. Gent 2018, p. 63-69.

Lotte Hellinga, 'William Caxton, Colard Mansion, and the Printer in Type 1'. In: Bulletin du Bibliophile 2011, p. 86-114 [republished in Lotte Hellinga, Incunabula in Transit. People and Trade. Leiden 2018, p. 286-322].

The History of Oliver of Castile. Ed. by Robert Edmund Graves. London 1898.

Keesman, Wilma, 'Jacob Bellaert en Haarlem'. In: Haarlems Helicon. Literatuur en toneel te Haarlem vóór 1800. Ed. by E.K. Grootes. Hilversum 1993, p. 27-48.

Keesman, Wilma, De eindeloze stad. Troje en Trojaanse oorsprongsmythen in de (laat)middeleeuwse en vroegmoderne Nederlanden. Hilversum 2017.

Kok, Ina, Woodcuts in Incunabula Printed in the Low Countries. 4 vols. Houten 2013.

Kuiper, Willem, ‘Briseïda. De identiteit van een 'middeleeuws' romanpersonage'. In: Simulacrum, het eigentijdse tijdschrift voor kunst en cultuur, themanummer Identiteit, 12 (2004), p. 17-19.

Kuiper, Willem, 'Die Destructie van Jherusalem in handschrift en druk'. In: Voortgang, jaarboek voor de neerlandistiek 25 (2007), p. 67-88.

Kuiper, Willem, 'Die Destructie van Jherusalem'. In: Bibliotheek van Middelnederlandse Letterkunde, nieuwe digitale reeks. Ed. by Willem Kuiper 2008-2016 (URL: http://cf.hum. uva.nl/dsp/scriptamanent/bml/Destructie_van_Jherusalem/Destructie_van_Jherusalem.

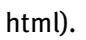

Kuiper, Willem, 'Die vergaderinge der historien van Troyen'. In: Bibliotheek van de Middelnederlandse letterkunde. Nieuwe digitale reeks. Ed. by Willem Kuiper. Amsterdam 2008-2016 (URL: http://cf.hum.uva.nl/dsp/scriptamanent/bml/Vergaderinge_der_histor ien_van_Troyen/Vergaderinge_der_historien_van_Troyen.html).

Kuiper, Willem, 'Galien Rethore: de editie'. In: Neerlandistiek. Online tijdschrift voor taal- en letterkundig onderzoek (March 23, 2018) (URL: http://www.neerlandistiek.nl/2017/02/ga lien-rethore-de-editie/).

Kuiper, Willem, 'Galien Rethore online'. In: Neerlandistiek. Online tijdschrift voor taal- en letterkundig onderzoek (March 23, 2018) (URL: http://www.neerlandistiek.nl/2016/12/ga lien-rethore-on-line/).

Het leven en de fabels van Esopus. Ed. by Hans Rijns and Willem van Bentum. Hilversum 2016. Oosterman, Johan, 'Franse en Nederlandse letterkunde in middeleeuws Vlaanderen'. In: Literaire bruggenbouwers tussen Nederland en Frankrijk. Receptie, vertaling en cultuuroverdracht sinds de Middeleeuwen. Ed. by Maaike Koffeman, Alicia Montoya and Marc Smeets. Amsterdam 2017, p. 29-47.

Pairet, Ana, 'Medieval Bestsellers in the Age of Print: Melusine and Olivier de Castille'. In: The Medieval Author in Medieval French Literature. Ed. by Virginie Greene. New York 2006, p. 189-204.

Paris e Vienna, romanzo cavalleresco. Ed. by Anna Maria Babbi. Padova 1991.

Pierre de Provence et la Belle Maguelonne. Ed. by Anna Maria Babbi. Soveria Mannelli 2003.

Resoort, Rob, 'Een proper profitelijc boec. Eind vijftiende en zestiende eeuw'. In: De hele Bibelebontse berg. De geschiedenis van het kinderboek in Nederland en Vlaanderen van de middeleeuwen tot heden. Ed. by Nettie Heimeriks and Willem van Toorn. Amsterdam 1989, p. 41-103.

Resoort, Rob, 'De presentatie van drukwerk in de volkstaal in de Nederlanden tot 1501: waar zijn de auteurs, vertalers en opdrachtgevers? Een verkenning'. In: Geschreven en 
gedrukt. Boekproductie van handschrift naar druk in de overgang van Middeleeuwen naar moderne tijd. Ed. by Herman Pleij, Joris Reynaert et al. Gent 2004, p. 177-206.

Ricci, Mariagrazia, 'Robert le Diable'. In: Nouveau Répertoire de mises en prose (XIVe-XVI ${ }^{e}$ siècle). Ed. by Maria Colombo Timelli et al. Paris 2014, p. 753-760.

Robrecht de Duyvel. Ed. by Rob Resoort. Muiderberg 1980.

Rouzet, Anne, Dictionnaire des imprimeurs, libraires et éditeurs des XV et XVI $I^{e}$ siècles dans les limites géographiques de la Belgique actuelle. Nieuwkoop 1975.

Sánchez-Martí, Jordi, 'The Printed Transmission of Medieval Romance from William Caxton to Wynkyn de Worde, 1473-1533'. In: The Transmission of Medieval Romance: Metres, Manuscripts and Early Prints. Ed. by Ad Putter and Judith A. Jefferson. Cambridge 2018, p. 170-190.

Suard, F., 'Pierre Desrey et La Généalogie de Godefroy de Bouillon'. In: Les épopées de la croisade. Ed. by K.H. Bender and H. Kleber. Special issue of Zeitschrift für französische Sprache und Literatur 11 (1987), p. 151-162.

Vermeulen, Yves, Tot profijt en genoegen. Motiveringen voor de produktie van Nederlandstalige gedrukte teksten 1477-1540. Groningen 1986.

De vijfhonderdste verjaring van de boekdrukkunst in de Nederlanden. Catalogus. Brussel 1973.

Vinck, Pierre, 'Het volksboek Die Historie van Peeter van Provencen ende die schoone Maghelone van Napels'. In: Jaarboek De Fonteine 27 (1976-1977), p. 3-45.

Wackers, Paul, 'Gheraert Leeu as a Printer of Fables and Animal Stories'. In: Reinardus, Yearbook of the International Reynard Society 20 (2007-2008), p. 128-152.

Wang, Yu-Chiao, 'Caxton's Romances and Their Early Tudor Readers'. In: Huntington Library Quarterly 67 (2004), p. 173-188.

Zeldenrust, Lydia, Mutations of an Animal-Human Hybrid Monster: The Western European Mélusine Translations (c. 1400-1600). Doctoral thesis Queen Mary University of London 2015. 